\title{
The economic determinants of party support for European integration
}

\author{
March 30, 2017
}

\begin{abstract}
Parties and their elites play an important role in shaping public opinion towards European integration. As determinants of party support for European integration the literature has identified ideological and strategic electoral motives. In this article we examine the impact of economic factors on party support for European integration. We find that party support from right-wing parties is larger in countries with greater financial benefits from the EU budget. On the contrary, benefits from trade creation by the introduction of the euro as a common currency shows no significant influence on party support. In the period after the introduction of the euro we find that right-wing parties where much more Eurosceptical than left-wing parties when their country did not fulfill the Maastricht debt or deficit criteria. We also observe more support for European integration by left-wing parties in countries that would benefit from welfare state convergence due to European integration. While our analysis indicates that different economic factors always have been important to explain party support for European integration, we also find that, in the period after the financial crisis in 2008, these motives have gained importance at the expense of the ideological motives.
\end{abstract}

Key words: European Integration; Party Ideology; Maastricht Criteria; EU Budget; Benefits from Trade; Welfare State Convergence 


\section{Introduction}

The European Union (EU) represents a unique process of economic and political integration in recent history. Never since World War II have sovereign countries renounced their competencies on economic and political issues to such a great extent as in the process of European integration. ${ }^{1}$ Throughout most of this process there seemed to be a consensus that more integration was beneficial for all EU members. As a consequence, the European Union has assumed more and more competences from its member countries and has steadily gained new members. So, the EU grew from 6 countries in 1952 to 28 in 2013. However, scepticism of citizen on the benefits from European integration has also grown in many member countries. Thus, the United Kingdom has become the first member country to leave the EU after the referendum in 2016, where a majority voted against remaining in the EU. But since the last decade criticism had already grown in numerous other member countries. For example, in 2005 France and the Netherlands rejected the EU constitution in a referendum. As a consequence, in six other EU member countries this referendum was cancelled or postponed indefinitely. Even in Spain, a country in which support for European integration traditionally has been considerable, recently, the supporters of the EU have become the minority for the first time. ${ }^{2}$

The literature has shown that parties and their elites play an important role in shaping public opinion towards European integration (De Vries and Edwards, 2009; Gabel and Scheve, 2007; Steenbergen et al., 2007; among others). But what are the determinants of party support for European integration? Here, the literature has focused basically on two kinds of determinants. The first of these is party ideology or identity, which has been found to be related to parties' positioning on European integration according to an inverted U-relationship, with central parties being pro-integrationist and extreme parties being Euro-sceptical (Aspinwall, 2002; Hellström, 2008; Hix, 1999; Hix and Lord, 1997; Hooghe and Marks, 1999; Hooghe et al., 2002; Marks and Steenbergen, 2002; Marks and Wilson, 2000; Marks et al., 2002). The second class of determinants of party support that the literature has considered are related to parties' electoral strategies. While well-established parties occupying the ideological centre follow the mainstream and take median voter positions on European integration, peripheral parties try to attract unsatisfied voters by taking more radical positions (Hellström, 2008). Thus, parties in government which have been widely responsible for advances in the European integration process are found to be more pro-integrationist than parties in the opposition. The same is true for parties with greater electoral success while minority extreme parties are found to be more sceptical towards European integration (Hellström, 2008; Marks et al., 2002).

In this article we extend the analysis of parties' strategic choice of positioning towards European integration by studying the role of economic factors that have yet not been considered explicitly in the literature. ${ }^{3}$ This is surprising for two reasons. First, as the EU is primarily an economic union that has been designed to facilitate trade and market integration, economic factors should be considered as important determinants of support for European integration. Second, apart from national and ideological identity considerations, utilitarian motives captured by economic variables have been found

\footnotetext{
${ }^{1}$ Other examples in which countries have renounced to economic competencies are the foundation of supra-state institutions like the World Trade Organization (WTO) or the North American Free Trade Agreement (NAFTA). How the creation of supranational institutions has limited the influence of parties in OECD countries on social expenditure, for example, has been analyzed recently by Herwartz and Theilen (2014).

${ }^{2}$ See Pew Research Center (2013), a summary of the 2013 Spring Pew Global Attitudes Survey.

${ }^{3}$ Of course, economic factors are also related with ideological party positions and, therefore, to some extent also implicitly considered in previous studies. Moreover, recent studies on the effects of the Eurozone crisis have shown that economic factors are more and more determinant for voting behaviour in the European parliament (Braghiroli, 2015; Otjes and Van der Veer, 2016).
} 
to play a role in studies on public opinion formation about the European integration process (Anderson and Reichert, 1996; Brinegar and Jolly, 2005; Christin, 2005; Doyle and Fidrmuc, 2006; Eichenberg and Dalton, 1993; Garry and Tilley, 2009; Hooghe and Marks, 2004; McLaren, 2004), and, therefore, should also influence party positions on European integration.

That economic factors might indeed influence party positioning towards European integration can be seen from Figure 1. We observe that party support from parties of the same ideological spectrum but from different countries varies with the country's direct monetary benefits from EU membership or its debt and inequality position relative to the EU median. Furthermore, we find that these variations also depend on party ideology, i.e., affect differently left-wing and right-wing parties, and that the impact of these economic variables on party positioning towards European integration may have changed over time. To uncover the political and economic determinants that have driven party support for European integration over the last three decades, we use data from 297 political parties in 24 countries collected in nine waves $(1984$ - 2014) to test five hypotheses. The first hypothesis refers to ideological and electoral strategy motives that have already been proved to influence party contestation over European integration (for example, see Hellström, 2008 and Marks et al., 2002). The remaining hypotheses are new and analyze the channel through which economic factors influence parties' strategies regarding their choice of support for European integration. As such factors we consider, first, the direct and indirect economic and monetary benefits. Second, we analyse whether the extent to which parties' countries were affected by European regulation has influenced their support for European integration. Finally, we test whether distributional effects of European integration have influenced party support.

Our results indicate that economic factors indeed play a crucial role to explain party support for European integration. Firstly, we obtain that party support from right-wing parties is larger in those countries in which the payments from the EU exceed the contributions to the EU budget. On the contrary, the indirect benefits through trade creation from the adoption of the euro as a common currency have not significantly increased support for European integration. Secondly, we find that debt and deficit control agreed upon in the Maastricht Treaty has had considerable impact on party support for European integration after 2002. Specifically, the non-compliance of debt and/or deficit criteria has increased Euroscepticism of right-wing parties. Furthermore, our results indicate that parties in countries with inequality differences are more in favour of European integration. This is particularly the case for left-wing parties. We can also conclude that in the period after the financial crisis in 2008 and under the ongoing sovereign debt crisis economic motives have gained importance at the expense of ideological motives.

Apart from the novelty of analysing the relevance of economic factors to the party support for European integration, this paper makes two other contributions to the literature. First, while previous studies have usually used pooled data and have assumed cross-sectional homogeneity (and, thus, neglected differences in the importance of the relationship at different times), our analysis is based on cross-sectional estimation, which controls for time-specific effects. This allows to account for the changing focuses of European integration (single market, common currency, EU enlargement, fiscal harmonization, etc.) and the context of this process (financial crisis, sovereign debt crisis, etc.). Second, our study includes a larger set of countries and more time periods, which provides new insights into the evolution of party support over time and of party positioning on European integration in new EU member countries.

The remainder of this article is organized as follows. Section 2 motivates the hypotheses subjected to empirical testing. Section 3 introduces the data and outlines the estimation procedure. Results 
are discussed in Section 4. Finally, in Section 5 the results are summarized and their relevance is discussed.

\section{Hypotheses}

A party's final objective is to maximize electoral support so that it can implement its policies. According to Hix and Lord (1997) and Taggart (1998), major parties support European integration because their positioning in favour of mainstream policy issues allows them to minimize intra-party tensions. Therefore, parties protect the status quo with a neutral position on European integration on which they might be internally divided (Marks et al., 2002; Parsons and Weber, 2011; Van de Wardt et al., 2014). Minor parties take advantage of the resulting convergence of the policy positions of major parties by formulating extreme positions on European integration in an attempt to attract votes from Euro-scepticals or to promote Eurosceptisism (Hooghe et al., 2002; Kriesi et al., 2008; De Vries and Edwards, 2009; Hobolt and Tilley, 2016). In the case of radical left-wing parties they oppose EU integration because of its 'neoliberal' character (March, 2011), while radical right-wing parties oppose Europe integration because it yields a loss of national sovereignty and identity (Mudde, 2007). The success of radical parties in turn influences party positioning regarding the support of European integration of mainstream parties (Hooghe and Marks, 2009). Thus, Meijers (2017) finds that "the centre-left is more affected by Eurosceptic contagion as it is influenced by both radical right and radical left Eurosceptic success, whereas the centreright is only susceptible to radical right success". This affects not only their overall positioning towards European integration but also the emphasis of new issues (Abou-Chadi, 2014). In this context, we analyze how economic factors have influenced party support for European integration. Our analysis is based on five hypotheses. The first hypothesis refers to the ideological and strategic electoral motives that have already been analysed in the literature:

H1: Ideology and strategic electoral motives determine the party position regarding European integration. Party support and ideology follow an inverted U-shape relationship and mainstream parties are supporters of European integration.

This hypothesis follows Marks et al. (2002) in assuming that parties are organizations with embedded ideologies that are grounded on 'Weltanschauungen' that constitute the basis for their positioning towards European integration. In particular, as far as European integration is concerned, party positioning is often related to the historical role that parties played in this integration process. According to the literature, party positioning on the issue of European integration can be located in a two dimensional space (Hellström, 2008; Hooghe and Marks, 1999; Hooghe et al., 2010; Marks and Steenbergen, 2002; Marks and Steenbergen, 2004; Marks and Wilson, 2000; Marks et al., 2002). One dimension measures parties' economic position on market organization (from regulated capitalism to neo-liberalism) and the other considers the extent to which decision making is centralized (from regionalism to a supranationalism). While these two dimensions are in principle independent, they are sometimes closely related to each other and highly correlated to the party position on an ideological left/right dimension. Thus, extreme left- and right-wing parties are strongly opposed to European integration; social democratic and conservative parties are generally moderately in favour; and liberal parties are strongly in favour. This results in an inverted U-shaped relationship between ideology (left-right position in the general ideological spectrum) and party support for European integration (Hellström, 2008; Marks et al., 2002). Furthermore, mainstream parties with higher electoral support 
that have often been in government and which can be made responsible for the current state of European integration have a more favourable position towards European integration than minor radical parties that were mostly excluded from government (Marks et al., 2002; Hobolt and De Vries, 2012).

With the next hypotheses we contribute to the literature by considering how economic factors influence parties' strategic choice of support for European integration. Specifically, we analyse whether the economic costs and benefits of European integration have an influence on party positioning in favour or against European integration in different member countries. The economic dimension of European integration plays an important role in party positioning on this issue as can be seen from party manifestos (De Vries and Edwards, 2009; Hooghe et al., 2002; Marks et al., 2002). While rightwing parties highlight the economic benefits from European integration by market liberalization, left-wing parties value European integration by its consequences on inequality. Moreover, the loss of sovereignty that goes along with European integration because of the loss of control on national policies situates extreme parties (both on the left and the right of the ideological spectrum) as opposed to European integration. In the empirical part of this paper, we take these differences in party evaluations of the economic consequences of European integration into account by interacting our economic performance variables with party ideology.

Our second hypothesis considers the direct economic benefits of European integration that have also been found to have a positive influence on citizen support for European integration (Anderson and Reichert, 1996; Brinegar and Jolly, 2005; Eichenberg and Dalton, 1993; Garry and Tilley, 2009; Hooghe and Marks, 2004; McLaren, 2004).

H2: Parties' positioning regarding European integration depends positively on the financial net benefits from integration with a larger effect for right-wing parties.

These benefits can be measured in various ways. As an initial measure, we consider the difference between the member countries' contribution payments to the EU budget and the expenditure of the EU in these countries. While these (net) expenditures are obviously only a part of the economic benefits of EU membership, they need to be taken into account for several reasons. On the one hand, both the contributions to the EU budget and the EU expenditures in member countries are the result of extensive negotiations between member countries. For example, the UK corrections, which reduced the contributions of the UK to the EU budget, were agreed to by the 1984 Fontainebleau European Council after long negotiations. Their press coverage and role in the national elections made voters in member countries more aware of the financial benefits and costs of European integration. Therefore, the position of voters regarding European integration should depend on these benefits and costs and, as a consequence, party positions towards European integration should also depend on them. On the other hand, because of limited rationality, voters tend to give greater value to direct costs and benefits rather than the indirect costs and benefits of European integration, which are, furthermore, much more difficult to measure. Thus, both voters and parties will give more importance to the financial costs and benefits than to other advantages and disadvantages of European integration. We expect this effect to be more pronounced for right-wing parties as these especially highlight the economic benefits from European integration.

Another important advance in European integration has been the creation of the European Monetary Union (EMU). We state our third hypothesis as:

H3: Parties' positioning regarding European integration depends positively on the economic benefits 
through EMU induced trade creation with a more notable effect for right-wing parties.

An important argument in favour of the EMU is that a common market with a common currency increases trade among EMU member countries. According to Frankel and Rose (2002), the formation of a currency union allows member countries to triple trade with other currency member countries without diverging trade from non-member countries. They also find that, in the mid-run, a percent increase in total trade raises income per capita by one-third of a percent. This means that the economic benefits from the EMU should be substantial, particularly for large and centrally located economies that, according to the gravity model of trade, should obtain the largest benefits. Therefore, as a second measure of economic benefits, we consider a country's benefits from EMU induced trade which should be positively related to party positioning in favour of European integration in these countries. One might expect voters hardly to be aware of these indirect benefits and that they, therefore, should have no significant impact on party support for European integration. However, firms will be aware of these benefits and will through their financial support to parties intent also to convince voters that European integration is beneficial. In line with this reasoning, total trade, as a measure related to the one used in this study, has been found to have a positive influence on citizens' support for European integration in Anderson and Reichert (1996), Eichenberg and Dalton (1993) and McLaren (2004). As before, this effect should be stronger for right-wing parties.

The fourth hypothesis we formulate considers the impact of the centralization of decision making implied by European integration on party support for this process.

H4: Party support for European integration decreases with the degree by which the party's country is affected by supranational regulation.

As mentioned above, European integration implies the centralization of decision making. New supranational institutions assume competencies that formerly belonged to the governments of the member countries and, therefore, were under the control of national parties. This has especially affected economic competencies. The Maastricht criteria in 1992 were a first attempt to control government deficits and debt and, thereby, government spending at the national level. Another example is the creation of the EMU and the introduction of the euro, which delegated the control of the monetary policy in EMU member countries from national institutions to a supranational institution. With hypothesis 4 we analyse whether party positioning regarding European integration has changed in those countries that have been especially affected by the control of supranational European institutions. ${ }^{4}$ We use the Maastricht criteria to analyse whether the creation of supranational institutions had a significant influence on party positioning towards European integration in those countries with excessive budget deficits and debt, and which did not fulfil the three percent deficit criterion or the 60 percent debt criterion.

Finally, our fifth hypothesis is:

H5: Party support for European integration is larger (smaller) in countries with more (less) income inequality. This effect is particularly relevant for the support of left-wing parties.

\footnotetext{
${ }^{4}$ The role of supranational institutional change on the influence of party ideology on social expenditure has recently been analysed by Herwartz and Theilen (2014). They find that, indeed, the creation of supranational institutions has limited the influence of parties on social spending in the OECD during the last two decades.
} 
As European integration means the convergence of member economies through trade, labour and capital market liberalization, we could interpret advances in European integration also as a reduction of inequality differences among EU member countries. This convergence of countries might cause a reduction (increase) of welfare standards in economies with larger (smaller) welfare states and, therefore, as suggested by Brinegar and Jolly (2005), increase the opposition (support) of parties to European integration in these countries. As a reduction of inequality is particularly relevant in the programmes of left-wing parties, we expect this effect to be stronger for left-wing parties than for right-wing parties.

\section{Data description and methodology}

Our analysis is based on the Chapel Hill Expert Survey which merges four data sets: Bakker et al. (2012), Hooghe et al. (2010), Polk et al. (2017) and Ray (1999). We use the data from nine waves of surveys (1984, 1988, 1992, 1996, 1999, 2002, 2006, 2010 and 2014) for 24 member countries of the European Union (Austria, Belgium, Denmark, Finland, France, Germany, Greece, Ireland, Italy, Netherlands, Portugal, Spain, Sweden and United Kingdom, for all years; Bulgaria, Czech Republic, Hungary, Latvia, Lithuania, Poland, Romania, Slovakia and Slovenia since 2002; and Estonia since 2006). The Chapel Hill Expert Survey contains evaluations by political scientists (experts) about party positions regarding European integration of major and minor parties in the experts' native country. The number of experts' responses depends on the year of the survey and ranges from 135 in 1984, with an average of 8 experts per country, to 337 in 2014, with an average of 12 experts per country. Because parties enter and exit, and several countries were included after 2002, our database is an unbalanced panel with a total of 268 different parties and 1415 observations with approximately 10 parties per country and year. ${ }^{5}$

Our dependent variable is party support for European integration, which measures party positions towards the European integration process in the year of the survey as the mean of the experts' individual rankings. European integration is a categorical variable that ranges from 1, strongly opposed, to 7, strongly in favour. Although the experts' answers are integer numbers, our dependent variable, as the mean of their evaluations, usually is not an integer.

To test hypothesis 1, as in Hellström (2008) and Marks et al. (2002), we use Ideology which is a categorical variable that measures parties' general ideological position from 0 , extreme left, to 10, extreme right. As in Hellström (2008), we also consider this variable in squared form (Ideology Squared), since the relationship between party support for European integration and ideology is nonlinear (radical parties at both ends of the ideological spectrum tend to be more Euro-sceptical than central parties). ${ }^{6}$ To test the importance of mainstream parties, we use Mainstream Party which takes value one when the party has more than $15 \%$ vote share, and zero otherwise. ${ }^{7}$

\footnotetext{
${ }^{5}$ See Bakker et al. (2012), Hooghe et al. (2010), Polk et al. (2017) and Ray (1999) for more details on the Chapel Hill Expert Survey and the distribution of parties over countries and years.

${ }^{6}$ The inverted U-form can be estimated with a second-order polynomial: European_Integration $=\beta_{0}+\beta_{1}$ Ideology + $\beta_{2}(\text { Ideology })^{2}$, where $\beta_{1}>0$ and $\beta_{2}<0$. Notice that support for European integration has its maximum at Ideology= $-\beta_{1} /\left(2 \beta_{2}\right)$ and, by definition, support by an extreme left-wing party is $\beta_{0}$ and by an extreme right-wing party is $\beta_{0}+10\left(\beta_{1}+10 \beta_{2}\right)$.

${ }^{7}$ We have also used Government participation, a dummy that takes value one for parties that are in office during the year of the survey, 0.5 (for both outgoing parties and entering parties) if there is a change of government in the survey year, and 0 otherwise. This measurement is different from Marks et al. (2002) whose variable takes value one when a party has participated in government at least once in the period 1965-1995. Furthermore, similar to Hellström (2008),
} 
Hypothesis 2 is contrasted with EU Net Expenditure which is the difference between a country's contributions to the EU budget and EU expenditure in this country. ${ }^{8}$ It is measured as a share of GDP in percentage points.

The variable used to test hypothesis 3 is Trade Benefits which are the benefits from EMU membership induced trade as a share of GDP quoted in percentage points. ${ }^{9}$ To calculate Trade Benefits we first estimate the linear trend in trade per GDP between EMU member countries for each of these countries before the introduction of the euro (from 1995 to 2001). Then, we calculate the differences between the observed trade and the forecasted trade for a fictitious scenario without the euro based on our trend estimates for the period before 2001. ${ }^{10}$ Finally, following Frankel and Rose (2002) who estimated the welfare effects of currency unions, we assume that a one percent increase in a country's overall trade (relative to GDP) raises income per capita by at least one-third of a percent. Per definition, Trade Benefits are non-negative and, for EMU non-member countries, zero. We consider Trade Benefits after the adoption of the euro (i.e., when a country introduces euro banknotes and coins).

To test the influence of the adoption of the Maastricht criteria in 1992 on party support for European integration, i.e., hypothesis 4, we use a dichotomous variable. Maastricht Non-Compliance take value one when government debt and/or deficit do not fulfill the Maastricht criteria, i.e., are more than $60 \%$ of GDP and/or more than $3 \%$ of GDP, respectively. We include this variables for the period starting in $1992 .{ }^{11}$

To test hypothesis 5, the influence of the size of the welfare state on party contestation over European integration, we use Inequality. Inequality is measured by the GINI index which ranges from 0, perfect equality, to 100, perfect inequality. Table A.2 shows that Inequality varies between 20 (Finland in 1988 and 1992, and Sweden 1984 and 1988) and 39 (Greece in 1984 and Latvia in 2006), respectively.

Finally, to account for business cycle effects, we use Growth Cycle and Unemployment Cycle. Growth Cycle measures the difference between a country's annual real per capita income growth rate and its trend. Similarly, Unemployment Cycle is the difference between a country's annual unemployment rate and its trend. In both cases country-specific trends are calculated with the HPfilter (Hodrick and Prescott, 1997).

Table A.1 summarizes the measurement of the variables and gives detailed information on the sources from which the data is obtained. Table A.2 gives some details on descriptive statistics. We observe that there is considerable heterogeneity among countries and parties. For example, EU Net Expenditure varies from -0.96 (a net contribution of $0.96 \%$ of GDP for the Netherlands in 2014) to

we have used Electoral Support which is measured as a party's share of total votes in the last national parliamentary elections before the survey year in percentage points. As all these variables are highly correlated with Mainstream Party, we use them alternatively to check the robustness of hypothesis 1 . The results are rather similar and available from the authors.

${ }^{8}$ We also include in EU Net Expenditure transfers from the EU to Bulgaria, Czech Republic, Hungary, Latvia, Lithuania, Poland, Romania, Slovakia and Slovenia before these countries were EU members.

${ }^{9}$ Notice that measuring trade as a share of GDP automatically accounts for business cycle fluctuations.

${ }^{10}$ The estimated effects of EMU-induced trade are in line with the predictions of the gravity model. Thus, trade benefits are highest for centrally located and large economies (Germany), medium for small centrally located economies (Austria, Belgium, Luxembourg, Netherlands) and large but more peripheral economies (France, Italy, Spain) and almost non-existent for small peripheral countries (Finland, Greece, Ireland, Portugal). Furthermore, for a control group of EMU non-member countries (Denmark, Sweden, UK), there are no effects of EMU induced trade.

${ }^{11}$ As an alternative measure we use simultaneaous non-compliance of the debt and deficit criteria which yields similar results available from the authors. 
6.66 (a net receipt of $6.66 \%$ of GDP for Greece in 1984). Heterogeneity of party support for European integration can also be observed in Figure 1 which display the distribution of party support for different survey years conditional on some economic variables. While we find an inverse U-shape relationship between party support for European integration and positioning on the general left-right ideology in all panels, we observe that this relationship changes over time and depends on different economic factors. As mentioned above, we regard this as an indicator for the relevance of economic factors as an explanation for the observed heterogeneity in party support for European integration. In the next section we comment on the detailed analysis of this question.

\section{Results}

As the influence of economic variables on party support for European integration is most likely to have changed over time, our analysis is based on cross-sectional OLS estimation for nine years available in the CHES-survey. Furthermore, we estimate a panel data model based on the full dataset clustering by time. The estimation results are displayed in Table 1. In what follows, we comment in detail on the estimation results regarding the hypotheses raised in Section 2.

Though our sample includes five more waves of expert surveys and nearly twice the number of countries, our results in the first two rows of Table 1 confirm the findings in Marks et al. (2002) and Hellström (2008). Radical parties on the extremes of the general ideological spectrum are opposed to European integration, while centrally located parties (liberal, Christian democratic and social democratic parties) widely support it. This gives rise to an inverted U-shape relationship between party support for European integration and left-right positioning on the general ideology. Furthermore, we find that this relationship has been largely stable over the whole sample period. However, for the years after the financial crisis in 2008 (i.e. 2010 and 2014) general support for European integration has reduced by more than 1 point for the overall Ideology. From Table 1 we observe that Mainstream Party has a significant and considerable influence on party support since 1988. The support of mainstream parties is between 0.41 and 0.84 points larger compared to that of other parties. ${ }^{12}$ Overall, the results lead us to accept hypothesis 1 of the importance of ideological motives for party support for European integration.

With hypothesis 2 we test whether the direct economic benefits and costs of EU membership influence party support for European integration. Regarding the influence of EU Net Expenditure we find a significant impact of this variable in most periods which, however, depends also on party Ideology. Right-wing parties turn out to care more about direct economic benefits from EU net expenditure than their left-wing counterparts. To get an impression of the size of the estimated effects consider the variation in support for European integration of three parties located at positions 3 ('moderate left'), 5 ('centrist') and 7 ('moderate right') of the ideological spectrum in two different countries: a country that net contributes $0.5 \%$ of its GDP to the EU budget and a country that net receives $0.5 \%$ of its GDP from the EU budget. The estimates in rows 4 and 5 in Table 1 for 2006, for example, indicate that the effect is almost no variation in support in case of the moderate left-wing party, an increase of support by 0.4 from the centrist party and an increase of support by 0.9 from the moderate right-wing party if we compare a party in a net contributor country with a party of the same ideology in a net

\footnotetext{
${ }^{12}$ Using Government Participation as an alternative measure of strategic electoral motives of party support for European integration we find similar results. Support for European integration of parties with government participation is between 0.4 and 1.3 points larger than the support of parties that are in opposition. The detailed results are available upon request from the authors.
} 
receiver country. Again, we find a substantial change for the years after the financial crisis in 2008. Thus, the 2010 and 2014 estimates indicate that EU Net Expenditure has completely lost its influence on party support for European integration. Overall, these results lead us to accept hypothesis 2 for the years before the crisis.

Hypothesis 3 is contrasted with Trade Benefits stemming from the creation of the European Monetary Union. While the estimation results indicate that these benefits have a small positive influence in the year of the introduction of the euro in 2002, the effect is non-significant in other years. The panel estimation results show no difference regarding the importance of trade benefits between left-wing and right-wing parties. Regarding the size of the effect, considering the estimates for the whole sample in the last column of Table 1, we find only a muted effect as even in the country with the overall highest trade benefits from monetary integration (Belgium in 2006 with a trade benefit of $8.28 \%$ of GDP) the support for European integration of a moderate left-wing party is by only 0.41 points higher than in a country with no trade benefits (the UK or Denmark, for example). For a centrist party the effect is even lower (0.18) and, contrary to our predictions, for a moderate right-wing party the effect is almost non-existent (-0.05). This indicates that these indirect benefits from European integration, contrary to the direct financial benefits, are of much less importance. This might be due either to the lack of awareness of these benefits to the general public or to the fact that these benefits are taken as granted once they are achieved and do not influence further party support for European integration. Therefore, we would not accept hypothesis 3, i.e., the importance of indirect economic benefits to party support for European integration, because we find no sizeable effect even in case of left-wing parties in countries with highest trade benefits.

\section{insert Table 1 Determinants of European Integration around here}

For the impact of Maastricht Non-Compliance on party support for European integration we find that the influence of this variable has varied over time. We can distinguish two periods. In the period post-Maastricht and before the introduction of the euro $(1992,1996,1999,2002)$ we find no significant effect of the violation of the Maastricht debt and deficit criteria on party support for European integration. This result is not surprising as during this period non-compliance of the criteria had no consequences. For example, in 1996, all countries did not fulfill at least one of the two criteria. In the second period, after the introduction of the euro $(2006,2010,2014)$, we observe considerable differences in party support for European integration regarding the evaluation of debt and deficit non-compliance. The estimates in Table 1 for 2006 indicate that while moderate left-wing parties increase support by 0.54 in case of non-compliance, moderate right-wing parties reduce support by 0.34. For 2010 and 2014, after the financial crisis in 2008, differences in the impact of Maastricht NonCompliance between a moderate left-wing and a moderate right-wing party are even more pronounced ( 1.40 and -0.30 for 2010 , and 0.96 and -0.23 for 2014, respectively). These results lead us to accept hypothesis 4 for the second period in the case of right-wing parties. By contrast, for left-wing parties we obtain the opposite result, i.e., support for European integration increases in the case of budgetary and or debt problems that lead to non-compliance with one of the Maastricht criteria.

Regarding hypothesis 5, we find that Inequality has a significant positive influence on party support for European integration in almost all years. Furthermore we find that the impact of Inequality as a determinant of party support for European integration decreases when we move to the right of the ideological spectrum. The estimates for 1992 displayed in Table 1 indicate that a 10 point increase in the Gini index (the difference between Finland and France or between Germany and Ireland that year, for example) increases party support for European integration from a moderate left-wing party more 
than 1 point, from a centrist party by 0.4 , while it has a slightly negative effect on support from a moderate right-wing party by -0.3 . However, for the years after the 2008 crisis, left-wing parties start to be more opposed to European integration than their right-wing counterparts in those countries with lower welfare standards where the effect also has lost some of its importance. Therefore, at least for the period before 2008, we accept hypothesis 5 .

Regarding the variables that control for the influence of the business cycle we obtain that Growth Cycle and Unemployment Cycle are in most of the periods insignificant at the 5 percent significance level. Regarding the year effects in the full sample estimation it turns out that only in 1992 and 2002 support has been significantly above that of the base year 1984 (by 0.4 points).

Summarizing our results we obtain that, apart from ideological motives, economic factors have always played an important role in shaping parties' strategy regarding their support for European integration. In the period before the 2008 crisis a country's net balance regarding EU contributions and payments has been the main economic factor in determining party support, particularly from right-wing parties. After the crisis the main economic factor for party support has been the impact of EU control of budget deficits and sovereign debt. Furthermore, for the period after the financial crisis in 2008 and under the ongoing sovereign debt crisis, economic motives have become more important at the expense of the ideological motives. Finally, while economic benefits from EMU induced trade creation have been substantial in some member countries, they have only played a negligible role for party support for European integration.

\section{Conclusions}

In this article we study whether, apart from ideological and strategic electoral motives, economic factors also influence party support for European integration. We find evidence for the importance of different economic factors as determinants of party support for European integration. Before the economic crisis in 2008 the most important variables to explain party support for European integration are party position on the general left-right ideology, EU net expenditure and differences in income inequality. After the crisis, party ideology has lost a substantial part of its influence and EU net expenditure and differences in income inequality play almost no role any more. By contrast, the extent to which countries are affected by the Maastricht criteria has gained considerable importance after the crisis where its influence on parties' European integration support depends on the party's ideology. Interestingly, this result is in line with recent studies on the effect of the economic crisis on voting behaviour in the European Parliament. Braghiroli (2015) obtains that the explanatory content of party ideology has become residual while voting behaviour after the crisis is determined by whether the costs and benefits presented by possible ways out of the crisis are considered as acceptable. In the same vein, Otjes and Van der Veer (2016) find that the Eurozone crisis has amplified the importance of the pro-/anti-EU dimension at the expense of the left-right dimension that traditionally has dominated the policy space in the European Parliament whereby this change is particularly pronounced for voting on economic issues.

Our results have some interesting policy implications for the future of the European integration process in particular and for processes of economic integration in general. First, as party support for European integration depends on economic factors, future advances in the European integration process will depend crucially on the economic benefits and their distribution among EU member countries. Second, as it is most likely impossible to obtain positive direct monetary benefits for all members by 
further integration policies, it becomes particularly important to accentuate the indirect benefits of such policies. For example, our results show that party support in those countries with largest benefits from EMU-induced trade is larger than in those countries with smaller benefits. However, the effect disappears after a certain time. We take this as evidence for the lack of awareness of these indirect benefits to the general public once they have been taken as granted. Therefore, it becomes particularly relevant to hint at the existence of these indirect benefits from European integration to maintain party support. Finally, while the European integration process unquestionably has its historic specificities, which can be traced back to experiences during and after World War II, it seems that this process, after considerable advances, has now arrived to a rather more complicated state of affairs that mean a turning point for some EU members. This teaches us valuable lessons that can be applied to other processes of economic integration.

\section{Appendix}

\subsection{Data Processing}

Parties' Electoral Support and Government Participation for 2010 and 2014 are from our own data. Some data about parties' ideology is missing in some survey years. We assumed that their position on general ideology is equal to their ideology quote in the closest survey year. Because of missing information, 54 observations on parties were not included in our sample. As GINI indexes are rather time invariant they are not collected annually in all countries and, thus, there is no information for all years to report Inequality. To prevent the loss of more observations, we estimate missing data by taking the average of the two closest observations in time.

insert Table Data definitions and sources around here

insert Table Descriptive statistics around here

\section{References}

Abou-Chadi T (2014) Niche Party Success and Mainstream Party Policy Shifts - How Green and Far-Right Parties Differ in Their Impact. British Journal of Political Science 46(2):1-20.

Anderson CJ and Reichert MS (1996) Economic Benefits and Support for Membership in the E.U.: A Cross-National Analysis. Journal of Public Policy 15(3):231-249.

Aspinwall M (2002) Preferring Europe: Ideology and National Preferences on European Integration. European Union Politics 3(2):81-111.

Bakker, R., de Vries C., Edwards E., Hooghe L., Jolly S., Marks G., Polk J., Rovny J., Steenbergen M. and Vachudova M. (2012) Measuring Party Positions in Europe: The Chapel Hill Expert Survey Trend File, 1999-2010. Party Politics. Epub ahead of print 29 November 2012. DOI: $10.1177 / 1354068812462931$.

Braghiroli S (2015) An Emerging Divide? Assessing the Impact of the Euro Crisis on the Voting Alignments of the European Parliament. The Journal of Legislative Studies 21(1):96-114. 
Brinegar AP and Jolly SK (2005) Location, Location, Location: National Contextual Factors and Public Support for European Integration. European Union Politics 6(2):155-180.

Christin T (2005) Economic and Political Basis of Attitudes towards the EU in Central and East European Countries in the 1990s. European Union Politics 6(1):29-57.

De Vries CE and Edwards EE (2009) Taking Europe to its Extremes: Extremist Parties and Public Euroscepticism. Party Politics 15(1):5-28.

Doyle O and Fidrmuc J (2006) Who Favors Enlargement?: Determinants of Support for EU Membership in the Candidate Countries' Referenda. European Journal of Political Economy 22:520-543.

Eichenberg RC and Dalton RJ (1993) Europeans and the European Community: The Dynamics of Public Support for European Integration. International Organization 47(4):507-534.

European Comission (2009) EU Budget 2008: Financial Report. Luxembourg: Publications Office of the European Union.

European Comission (2017) Financial Programming and Budget. Available at: http://ec.europa.eu/budget/index_en.cfm (accessed February 2017).

Eurostat (2017) Eurostat Data Base. Available at: http://ec.europa.eu/eurostat/data/database (accessed Februrary 2017).

Frankel J and Rose A (2002) An estimate of the Effect of Common Currencies on Trade and Income. The Quarterly Journal of Economics 117(2):437-466.

Garry J and Tilley J (2009) The Macroeconomic Factors Conditioning the Impact of Identity on Attitudes towards the EU. European Union Politics 10(3):361-379.

Gabel MJ and Scheve K (2007) Mixed Messages: Party Dissent and Mass Opinion on European Integration. European Union Politics 8:37-59.

Hellström J (2008) Party Responses to Europe: the Role of Ideology for National Political Parties' Positions on European Integration. Journal of European Public Policy 15(2):189-207.

Herwartz H and Theilen B (2014) Partisan Influence on Social Spending under Market Integration, Fiscal Pressure and Institutional Change. European Journal of Political Economy 34:409-424.

Hix S (1999) Dimensions and Alignments in European Union Politics: Cognitive Constraints and Partisan Responses. European Journal of Political Research 35(2):69-106.

Hix S and Lord C (1997) Political Parties in the European Union. London: Macmillan Press.

Hobolt SB and De Vries CE (2012) When Dimensions Collide: The Electoral Success of Issue Entrepreneurs, European Union Politics 13(2):246-268.

Hobolt SB and Tilley J (2016). Fleeing the Centre: The Rise of Challenger Parties in the Aftermath of the Euro Crisis, West European Politics 39(5): 971-991.

Hodrick RJ and Prescott EC (1997) Postwar U.S. Business Cycles: An Empirical Investigation. Journal of Money, Credit and Banking 29: 1-16. 
Hooghe L and Marks G (1999) The Making of a Polity: the Struggle over European Integration. In: Kitschelt M, Lange P, Marks G and Stephens JD (eds) Continuity and Change in Contemporary Capitalism. Cambridge: Cambridge Studies in Comparative Politics, Cambridge University Press, chapter 3 .

Hooghe L and Marks G (2004) Does Identity or Economic Rationality Drive Public Opinion on European Integration? Political Science and Politics 35(8):965-989.

Hooghe L and Marks G (2009) A Postfunctionalist Theory of European Integration: From Permissive Consensus to Constraining Dissensus. British Journal of Political Science 39(1):1-23.

Hooghe L, Marks G and Wilson CJ (2002) Does Left/Right Structure Party Positions on European Integration? Comparative Political Studies 37:415-420.

Hooghe L, Bakker R, Brigevich A, de Vries C, Edwards E, Marks G, Rovny J and Steenbergen M (2010) Reliability and Validity of Measuring Party Positions: the Chapel Hill Expert Surveys of 2002 and 2006. European Journal of Political Research (4):684-703.

International Monetary Fund. 2010. A Historical Public Debt Database. IMF Working Papers 10/245.

Kriesi H, Grande E, Lachat R, Dolezal M, Bornschier S and Frey T (2008) West European Politics in the Age of Globalization. Cambridge: Cambridge University Press

March L (2011) Radical Left Parties in Europe. London: Routledge.

Marks G and Steenbergen M (2002) Understanding Political Contestation in the European Union. Comparative Political Studies 35(8):879-892.

Marks G and Steenbergen M (eds) (2004) European Integration and Political Conflict. Cambridge: Cambridge University Press.

Marks G, Wilson CJ and Ray L (2002) National Political Parties and European Integration. American Journal of Political Science 46(3):585-594.

Marks G and Wilson CJ (2000) The Past in the Present: a Cleavage Theory of Party Response to European Integration. British Journal of Political Science 30(3):433-459.

McLaren L (2004) Opposition to European Integration and Fear of Loss of National Identity: Debunking a Basic Assumption Regarding Hostility to the Integration Project. European Journal of Political Research 43:895-911.

Meijers M (2017) Contagious Euroscepticism. The Impact of Eurosceptic Support on Mainstream Party Positions on European Integration. Party Politics, forthcoming.

Mudde C (2007) Populist Radical Right Parties in Europe. Cambridge: Cambridge University Press.

The Organisation for Economic Co-operation and Development, OECD (2017) OECD Data Base Available at: http://stats.oecd.org/ (accessed February 2017).

Otjes S and Van der Veer H (2016) The Eurozone Crisis and the European Parliament's Changing Lines of Conflict. European Union Politics 17(2):242-261.

Parsons C and Weber T (2011) Cross-Cutting Issues and Party Strategy in the European Union. Comparative Political Studies 44(4):383-411. 
Pew Research Center (2013) The New Sick Man of Europe: the European Union. Available at: http://www.pewglobal.org/2013/05/13/the-new-sick-man-of-europe-the-european-union/ (accessed May 2013).

Polk J, Rovny J, Bakker R, Edwards E, Hooghe L, Jolly S, Koedam J, Kostelka F, Marks G, Schumacher G, Steenbergen M, Vachudova M and Zilovic M (2017) Explaining the Salience of AntiElitism and Reducing Political Corruption for Political Parties in Europe with the 2014 Chapel Hill Expert Survey data. Research 83 Politics January-March:1-9.

Ray L (1999) Measuring Party Orientations toward European Integration: Results from an Expert Survey. European Journal of Political Research 36(2):283-306.

Steenbergen MR, Edwards EE and De Vries CE (2007) Who's Cueing Whom? Mass-Elite Linkages and the Future of European Integration. European Union Politics 8:13-35.

Taggart P (1998) A Touchstone of Dissent: Euroscepticism in Contemporary Western European Party Systems. European Journal of Political Research 33(3):363-388.

United Nations University and World Institute for Development Economics Research, UNU-WIDER (2013) World Income Inequality Database. Available at: http://www.wider.unu.edu/research/Database/en_GB/wiid/ (accessed March 2013).

Van de Wardt M, De Vries CE and Hobolt SB (2014) Exploiting the Cracks: Wedge Issues in Multiparty Competition. The Journal of Politics, 76(04): 986-999.

World Bank (2017) World Bank Open Data. Available at: http://data.worldbank.org (accessed February 2017). 


\begin{tabular}{|c|c|c|c|c|c|c|c|c|c|c|}
\hline & 1984 & 1988 & 1992 & 1996 & 1999 & 2002 & 2006 & 2010 & 2014 & 1984-2014 \\
\hline Ideology & $\begin{array}{c}2.270^{* * * *} \\
(0.457)\end{array}$ & $\begin{array}{c}2.541^{* * *} \\
(0.334)\end{array}$ & $\begin{array}{c}2.749^{* * *} \\
(0.257)\end{array}$ & $\begin{array}{c}2.717^{* * *} \\
(0.392)\end{array}$ & $\begin{array}{c}3.608^{* * *} \\
(0.621)\end{array}$ & $\begin{array}{c}2.773^{* * *} \\
(0.362)\end{array}$ & $\begin{array}{c}2.894^{* * *} \\
(0.452)\end{array}$ & $\begin{array}{c}1.637^{* * * *} \\
(0.294)\end{array}$ & $\begin{array}{c}1.385^{* * *} \\
(0.376)\end{array}$ & $\begin{array}{c}2.495^{* * *} \\
(0.125)\end{array}$ \\
\hline Ideology Squared & $\begin{array}{c}-0.172^{* * *} \\
(0.019)\end{array}$ & $\begin{array}{c}-0.175^{* * *} \\
(0.020)\end{array}$ & $\begin{array}{c}-0.172^{* * *} \\
(0.018)\end{array}$ & $\begin{array}{c}-0.162^{* * *} \\
(0.019)\end{array}$ & $\begin{array}{c}-0.198^{* * * *} \\
(0.015)\end{array}$ & $\begin{array}{c}-0.215^{* * *} \\
(0.014)\end{array}$ & $\begin{array}{c}-0.186^{* * *} \\
(0.016)\end{array}$ & $\begin{array}{c}-0.178^{* * *} \\
(0.014)\end{array}$ & $\begin{array}{c}-0.201^{* * *} \\
(0.014)\end{array}$ & $\begin{array}{c}-0.191^{* * *} \\
(0.006)\end{array}$ \\
\hline Mainstream Party & $\begin{array}{l}-0.056 \\
(0.359)\end{array}$ & $\begin{array}{l}0.544^{*} \\
(0.264)\end{array}$ & $\begin{array}{c}0.775^{* * *} \\
(0.229)\end{array}$ & $\begin{array}{c}0.689^{* *} \\
(0.234)\end{array}$ & $\begin{array}{c}0.843^{* * *} \\
(0.247)\end{array}$ & $\begin{array}{c}0.625^{* * *} \\
(0.171)\end{array}$ & $\begin{array}{c}0.456^{*} \\
(0.208)\end{array}$ & $\begin{array}{l}0.417^{*} \\
(0.170)\end{array}$ & $\begin{array}{l}0.409^{*} \\
(0.199)\end{array}$ & $\begin{array}{c}0.433^{* * *} \\
(0.076)\end{array}$ \\
\hline EU Net Expenditure & $\begin{array}{l}-0.301 \\
(0.282)\end{array}$ & $\begin{array}{c}-0.603^{*} \\
(0.241)\end{array}$ & $\begin{array}{c}-0.443^{*} \\
(0.194)\end{array}$ & $\begin{array}{c}-0.662^{* *} \\
(0.239)\end{array}$ & $\begin{array}{c}-1.987^{* * *} \\
(0.306)\end{array}$ & $\begin{array}{c}-0.632^{*} \\
(0.317)\end{array}$ & $\begin{array}{c}-0.743^{*} \\
(0.319)\end{array}$ & $\begin{array}{l}-0.018 \\
(0.181)\end{array}$ & $\begin{array}{c}0.192 \\
(0.128)\end{array}$ & $\begin{array}{c}-0.354^{* * *} \\
(0.077)\end{array}$ \\
\hline $\begin{aligned} \text { EU Net Expenditure } \\
\quad \times \text { Ideology }\end{aligned}$ & $\begin{array}{c}0.062 \\
(0.050)\end{array}$ & $\begin{array}{l}0.089^{+} \\
(0.047)\end{array}$ & $\begin{array}{l}0.095^{* *} \\
(0.032)\end{array}$ & $\begin{array}{c}0.139^{* *} \\
(0.042)\end{array}$ & $\begin{array}{c}0.392^{* * * *} \\
(0.072)\end{array}$ & $\begin{array}{l}0.166^{*} \\
(0.068)\end{array}$ & $\begin{array}{l}0.228^{* *} \\
(0.069)\end{array}$ & $\begin{array}{c}0.032 \\
(0.028)\end{array}$ & $\begin{array}{c}-0.030 \\
(0.025)\end{array}$ & $\begin{array}{c}0.070^{* * * *} \\
(0.015)\end{array}$ \\
\hline EMU Trade Benefits & & & & & & $\begin{array}{l}0.171^{+} \\
(0.094)\end{array}$ & $\begin{array}{c}0.112 \\
(0.081)\end{array}$ & $\begin{array}{c}0.026 \\
(0.141)\end{array}$ & $\begin{array}{c}0.050 \\
(0.097)\end{array}$ & $\begin{array}{l}0.092^{*} \\
(0.042)\end{array}$ \\
\hline EMU Trade Benefits & & & & & & -0.017 & 0.003 & -0.002 & -0.011 & $-0.014^{*}$ \\
\hline$\times$ Ideology & & & & & & $(0.017)$ & $(0.014)$ & $(0.025)$ & $(0.016)$ & $(0.007)$ \\
\hline Maastricht Non-compliance & & & $\begin{array}{c}-0.560 \\
(0.769)\end{array}$ & - & $\begin{array}{c}0.144 \\
(0.511)\end{array}$ & $\begin{array}{c}0.399 \\
(0.440)\end{array}$ & $\begin{array}{l}1.198^{* *} \\
(0.443)\end{array}$ & $\begin{array}{c}2.660^{* * * *} \\
(0.781)\end{array}$ & $\begin{array}{c}1.853^{* * *} \\
(0.518)\end{array}$ & $\begin{array}{c}1.009^{* * *} \\
(0.187)\end{array}$ \\
\hline $\begin{array}{l}\text { Maastricht Non-compliance } \\
\quad \times \text { Ideology }\end{array}$ & & & $\begin{array}{c}0.145 \\
(0.139)\end{array}$ & - & $\begin{array}{c}0.139 \\
(0.103)\end{array}$ & $\begin{array}{l}-0.045 \\
(0.079)\end{array}$ & $\begin{array}{c}-0.220^{* *} \\
(0.077)\end{array}$ & $\begin{array}{c}-0.422^{* *} \\
(0.140)\end{array}$ & $\begin{array}{c}-0.298^{* *} \\
(0.094)\end{array}$ & $\begin{array}{c}-0.107^{* *} \\
(0.035)\end{array}$ \\
\hline Inequality & $\begin{array}{c}0.078 \\
(0.092)\end{array}$ & $\begin{array}{c}0.234^{* * *} \\
(0.051)\end{array}$ & $\begin{array}{c}0.234^{* * *} \\
(0.054)\end{array}$ & $\begin{array}{c}0.277^{* * *} \\
(0.069)\end{array}$ & $\begin{array}{c}0.394^{* * *} \\
(0.092)\end{array}$ & $\begin{array}{l}0.110^{*} \\
(0.055)\end{array}$ & $\begin{array}{l}0.184^{*} \\
(0.074)\end{array}$ & $\begin{array}{r}-0.081^{+} \\
(0.047)\end{array}$ & $\begin{array}{c}-0.174^{* *} \\
(0.062)\end{array}$ & $\begin{array}{c}0.120^{* * * *} \\
(0.021)\end{array}$ \\
\hline $\begin{array}{l}\text { Inequality } \\
\quad \times \text { Ideology }\end{array}$ & $\begin{array}{l}-0.015 \\
(0.018)\end{array}$ & $\begin{array}{l}-0.025^{*} \\
(0.010)\end{array}$ & $\begin{array}{c}-0.038^{* * *} \\
(0.010)\end{array}$ & $\begin{array}{c}-0.039^{* *} \\
(0.015)\end{array}$ & $\begin{array}{c}-0.062^{* *} \\
(0.021)\end{array}$ & $\begin{array}{r}-0.019^{+} \\
(0.011)\end{array}$ & $\begin{array}{l}-0.033^{*} \\
(0.014)\end{array}$ & $\begin{array}{l}0.016^{+} \\
(0.009)\end{array}$ & $\begin{array}{l}0.030^{*} \\
(0.012)\end{array}$ & $\begin{array}{c}-0.017^{* * * *} \\
(0.004)\end{array}$ \\
\hline Growth Cycle & $\begin{array}{c}0.073 \\
(0.164)\end{array}$ & $\begin{array}{r}-0.261^{+} \\
(0.145)\end{array}$ & $\begin{array}{l}0.435^{*} \\
(0.210)\end{array}$ & $\begin{array}{l}-0.388 \\
(0.467)\end{array}$ & $\begin{array}{c}0.179 \\
(0.236)\end{array}$ & $\begin{array}{l}0.232^{+} \\
(0.128)\end{array}$ & $\begin{array}{l}-0.055 \\
(0.089)\end{array}$ & $\begin{array}{l}0.154^{+} \\
(0.079)\end{array}$ & $\begin{array}{l}0.125 \\
(0.143)\end{array}$ & $\begin{array}{l}0.097^{*} \\
(0.039)\end{array}$ \\
\hline Unemployment Cycle & $\begin{array}{c}1.694^{* * * *} \\
(0.412)\end{array}$ & $\begin{array}{c}0.806 \\
(0.539)\end{array}$ & $\begin{array}{l}-0.366^{*} \\
(0.179)\end{array}$ & $\begin{array}{l}-0.611 \\
(0.648)\end{array}$ & $\begin{array}{l}-0.185 \\
(0.300)\end{array}$ & $\begin{array}{l}-0.027 \\
(0.181)\end{array}$ & $\begin{array}{l}-0.138 \\
(0.165)\end{array}$ & $\begin{array}{l}-0.055 \\
(0.146)\end{array}$ & $\begin{array}{l}-0.059 \\
(0.195)\end{array}$ & $\begin{array}{c}0.004 \\
(0.045)\end{array}$ \\
\hline Constant & $\begin{array}{l}-1.943 \\
(2.222) \\
\end{array}$ & $\begin{array}{c}-5.408^{* * *} \\
(1.402) \\
\end{array}$ & $\begin{array}{c}-4.750^{* *} \\
(1.422)\end{array}$ & $\begin{array}{c}-6.171^{* * *} \\
(1.691) \\
\end{array}$ & $\begin{array}{c}-10.484^{* * * *} \\
(2.735) \\
\end{array}$ & $\begin{array}{l}-2.877 \\
(1.763) \\
\end{array}$ & $\begin{array}{l}-5.025^{*} \\
(2.289) \\
\end{array}$ & $\begin{array}{c}1.234 \\
(1.413) \\
\end{array}$ & $\begin{array}{l}4.212^{*} \\
(1.802) \\
\end{array}$ & $\begin{array}{c}-3.432^{* * *} \\
(0.611) \\
\end{array}$ \\
\hline Number of parties & 117 & 120 & 123 & 131 & 142 & 171 & 188 & 203 & 220 & 1415 \\
\hline Number of countries & 14 & 14 & 14 & 14 & 14 & 23 & 24 & 24 & 24 & 24 \\
\hline$R$-Squared & 0.468 & 0.533 & 0.620 & 0.549 & 0.639 & 0.605 & 0.508 & 0.497 & 0.487 & 0.488 \\
\hline
\end{tabular}

Table 1: Determinants of European Integration. OLS estimations. Standard errors are in parentheses. $+,{ }^{*}, * *, * * *$ indicate significance at the 10, 5, 1 and 0.1 percent level, respectively. The full sample estimation model (last column) is clustered by year with 1984 as the base year. Maasticht Non-compliance in 1996 is excluded as the variable is one for all observations. The complete table with the year effects is available under request from the authors. 


\begin{tabular}{|c|c|c|}
\hline Variable & Measurement & Source \\
\hline European Integration & $\begin{array}{l}\text { Parties' position towards European integra- } \\
\text { tion from } 1 \text { (strongly opposed) to } 7 \text { (strongly } \\
\text { in favour). }\end{array}$ & $\begin{array}{l}\text { Bakker et al. (2012), } \\
\text { Hooghe et al. (2010), } \\
\text { Polk et al. (2017) and } \\
\text { Ray (1999). }\end{array}$ \\
\hline Ideology & $\begin{array}{l}\text { Parties' general ideological position from } 0 \\
\text { (extreme left) to } 10 \text { (extreme right). }\end{array}$ & $\begin{array}{l}\text { Bakker et al. (2012), } \\
\text { Hooghe et al. (2010), } \\
\text { Polk et al. (2017) and } \\
\text { Ray (1999). }\end{array}$ \\
\hline Mainstream Party & $\begin{array}{l}\text { Dichotomous variable for parties with a share } \\
\text { of total votes higher than } 15 \% \text { in the last na- } \\
\text { tional government elections before the survey } \\
\text { year in percentage points. }\end{array}$ & $\begin{array}{l}\text { Bakker et al. (2012), } \\
\text { Hooghe et al. (2010), } \\
\text { Polk et al. (2017) and } \\
\text { Ray (1999). }\end{array}$ \\
\hline EU Net Expenditure & $\begin{array}{l}\text { EU expenditure in the country minus national } \\
\text { contributions to the EU budget as a share of } \\
\text { GDP in percentage points. }\end{array}$ & $\begin{array}{l}\text { Own calculation with } \\
\text { data from European } \\
\text { Comission (2009) and } \\
\text { European Comission } \\
\text { (2017). }\end{array}$ \\
\hline EMU Trade Benefits & $\begin{array}{l}\text { Benefits from EMU membership induced trade } \\
\text { (since 2002) as a share of GDP in percentage } \\
\text { points. }\end{array}$ & $\begin{array}{l}\text { Own calculation with } \\
\text { data from Eurostat } \\
(2017) \text {, EU trade since } \\
1988 \text { by CN8. }\end{array}$ \\
\hline $\begin{array}{l}\text { Maastricht } \\
\text { compliance }\end{array}$ & $\begin{array}{l}\text { Binary variable that takes value } 1 \text { when a } \\
\text { country has a government deficit larger than } \\
3 \% \text { of GDP and/or a government debt larger } \\
\text { than } 60 \% \text { of GDP; } 0 \text { otherwise. }\end{array}$ & $\begin{array}{l}\text { Own calculation with } \\
\text { data from International } \\
\text { Monetary Fund (2010) } \\
\text { OECD (2017) and Euro- } \\
\text { stat }(2017) \text {. }\end{array}$ \\
\hline Inequality & $\begin{array}{l}\text { GINI index that varies between } 0 \text { (perfect } \\
\text { equality) and } 100 \text { (perfect inequality). }\end{array}$ & $\begin{array}{l}\text { Eurostat }(2017) \text { and } \\
\text { UNU-WIDER (2013). }\end{array}$ \\
\hline Growth Cycle & $\begin{array}{l}\text { Difference between the country's annual real } \\
\text { per capita income growth rate and its trend } \\
\text { over the period 1980-2010 (base year for real } \\
\text { per capita income 2010). }\end{array}$ & $\begin{array}{l}\text { Own calculation with } \\
\text { data from OECD (2017) } \\
\text { and WDB (2017). }\end{array}$ \\
\hline Unemployment Cycle & $\begin{array}{l}\text { Difference between the country's annual un- } \\
\text { employment rate and its trend over the period } \\
\text { 1980-2014. }\end{array}$ & $\begin{array}{l}\text { Own calculation with } \\
\text { data from WDB (2017). }\end{array}$ \\
\hline
\end{tabular}

Table A.1: Data definitions and sources. The measurment of variables refers to the respective survey year if not indicated otherwise. 


\begin{tabular}{lrrrr}
\hline Variable & Mean & Std. Dev. & Min & Max \\
\hline European Integration & 4.83 & 1.80 & 1 & 7 \\
Ideology & 5.01 & 2.35 & 0 & 10 \\
Mainstream Party & 0.30 & 0.46 & 0 & 1 \\
EU Net Expenditure & 0.69 & 1.41 & -0.96 & 6.66 \\
EMU Trade Benefits & 0.69 & 1.41 & 0 & 8.28 \\
Maastricht Non-compliance & 0.71 & 0.46 & 0 & 1 \\
Inequality & 29.31 & 4.58 & 20 & 39 \\
Growth Cycle & 0.49 & 1.31 & -3.30 & 4.85 \\
Unemployment Cycle & 0.07 & 0.84 & -1.95 & 4.85 \\
\hline
\end{tabular}

Table A.2: Descriptive statistics. 

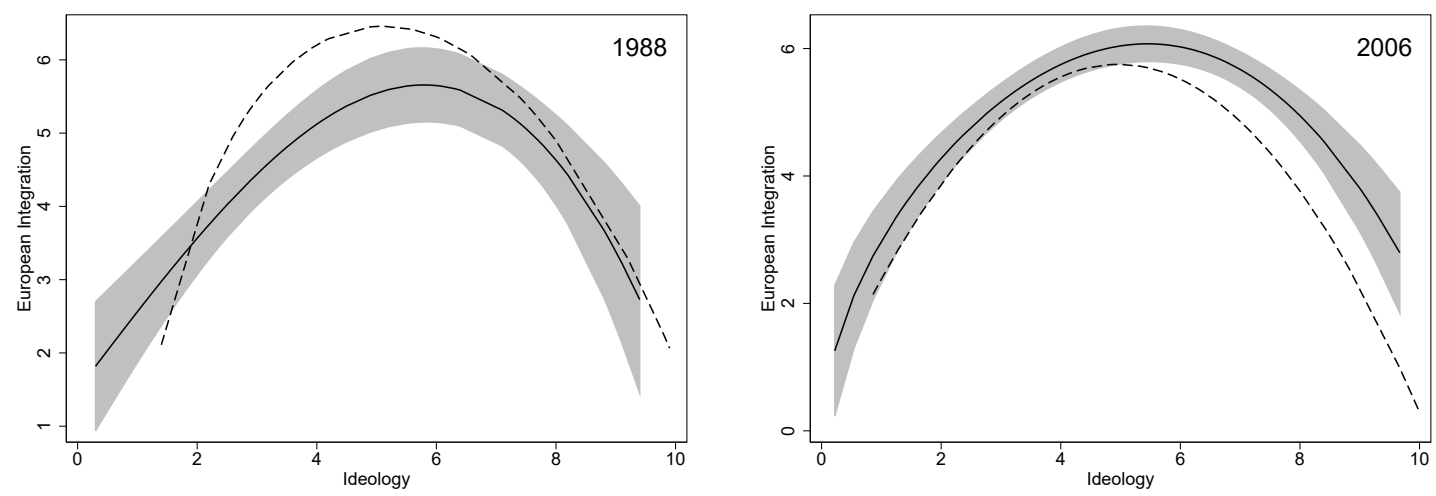

$-E U$ Net Benefits $\geq 0$

- $-E U$ Net Benefits $<0$
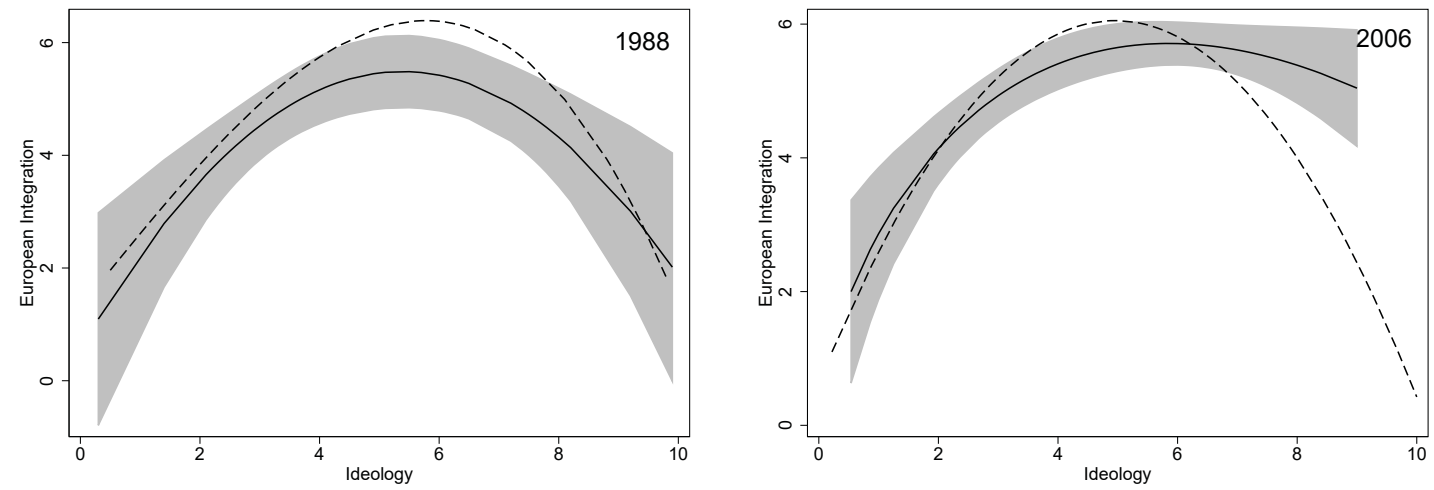

- Government Debt < Median Government Debt

- -Government Debt $\geq$ Median Government Debt
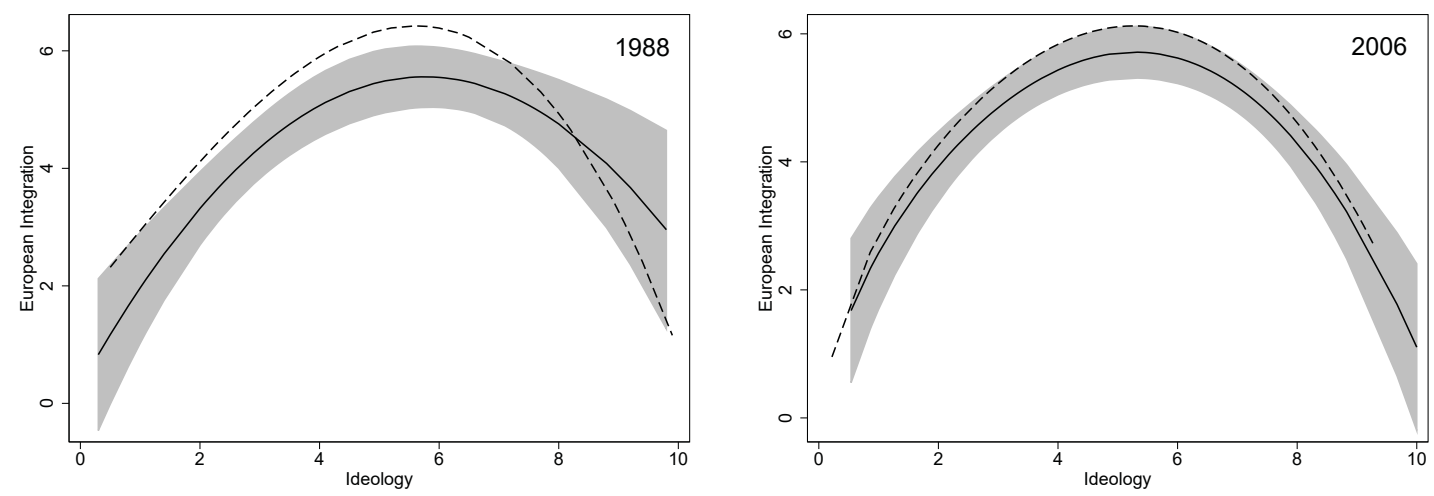

— Inequality < Median Inequality

- - Inequality $\geq$ Median Inequality

Figure 1: Relationship between party support for European integration (European Integration) and party position over the general left-right ideology spectrum (Ideology) conditional on countries' EU net benefits and government debt and inequality position relative to the EU median. 